\title{
Paradoks Perempuan Batak Toba: Suatu Penafsiran Hermeneutik terhadap Karya Sastra Ende Siboru Tombaga
}

\author{
RATIH BAIDURI \\ Fakultas Ilmu Sosial, Program Studi Pendidikan Antropologi, Universitas Negeri Medan, \\ Jl. Willem Iskandar Psr V - Kotak Pos No. 1589 Medan 20221. \\ email: ratihbaiduri215@gmail.com
}

\begin{abstract}
This paper attempts to analyze a literature Ende Siboru Tombaga (EST) by using hermeneutic paradigms. Women are usually not taken into account in the division of the inheritance if they have no brothers. The estate will fall into the hands of his father's brother (uncle) or father's sister's son. In the literature, EST expressed repeatedly injustice, wickedness, unrighteousness and discrimination against women who do not have the Batak Toba brother. EST literature can be considered as a counter culture against customs that discriminate against women tends to be considered. The paradox of women Batak Toba characterized by a situation that is culturally Toba Batak people with patrilineal system puts the male in a leading role in many areas of life. In reality, women Toba Batak work hard to provide for the family and the household.
\end{abstract}

Keywords: Karya Sastra EST, hermeneutik, paradoks, perempuan Batak Toba

\begin{abstract}
Abstrak. Tulisan ini berupaya menganalisis sebuah karya sastra Ende Siboru Tombaga (EST) dengan menggunakan paradigma hermeneutik. Perempuan biasanya tidak diperhitungkan dalam pembagian warisan jika tidak memiliki saudara laki-laki. Harta warisan akan jatuh ke tangan adik ayahnya (paman) atau putra adik ayah. Dalam karya sastra EST dinyatakan secara berulang-ulang ketidakadilan, kejahatan, ketidakbenaran dan diskriminasi terhadap perempuan Batak Toba yang tidak memiliki saudara lakilaki. Karya sastra EST dapat dianggap sebagai counter culture terhadap adat istiadat yang cenderung dianggap mendiskriminasi perempuan. Paradoks perempuan Batak Toba ditandai dengan situasi bahwa secara kultural orang Batak Toba dengan sistem patrilinealnya menempatkan laki-laki sebagai pemeran utama dalam berbagai bidang kehidupan. Dalam realitasnya perempuan Batak Toba bekerja keras dalam menafkahi keluarga dan rumah tangganya.
\end{abstract}

Kata Kunci: Karya Sastra EST, hermeneutik, paradoks, perempuan Batak Toba

\section{Pendahuluan}

Paradigma hermeneutik adalah aliran pemikiran filsafat yang muncul sebagai reaksi atas pemikiran-pemikiran ilmiah dan filosofis yang ada sebelumnya. Munculnya hermeneutik dapat dikatakan juga terkait dengan krisis yang dialami ilmu pengetahuan karena masih dominannya pengaruh filsafat positivisme dalam ilmu-ilmu humaniora dan sosial budaya. Aliran filsafat ini menolak dengan keras cengkraman filsafat positivisme dalam ilmu-ilmu humaniora dan sosial budaya.

Tulisan ini berkeinginan me review kembali dan menggunakan data penelitian yang dilakukan Sibarani dan Simanjuntak (1999) mengenai hak dan kedudukan perempuan Batak Toba yang tidak mempunyai saudara laki-laki dalam pembagian harta warisan, khususnya sebagaimana tergambar dalam karya sastra legendaries EST. Dengan data penelitian yang diperoleh dari tulisan ini kemudian dilakukan analisis berdasarkan paradigma hermeneutik.

\section{Pengertian dan Sejarah Hermeneutik}

Hermeneutik berasal dari kata hermeneuin, yang berarti menafsirkan atau seni memberikan makna, seni interpretasi

Received: 17 Oktober 2014, Revision: 25 April 2015, Accepted: 24 Juni 2015

Print ISSN: 0215-8175; Online ISSN: 2303-2499. Copyright@2015. Published by Pusat Penerbitan Universitas (P2U) LPPM Unisba Terakreditasi SK Kemendikbud, No.040/P/2014, berlaku 18-02-2014 s.d 18-02-2019 
(the art of interpretation). Istilah hermeneutik telah digunakan sejak abad pertengahan oleh gereja Kristen dan filosofer Augustine dari Hippo hingga merujuk kepada teks-teks kitab suci. Hermeneutik mulai dipakai dalam konteks ilmu pengetahuan klasik dalam arti spesifik dan terbatas. Prinsip hermeneutik pada waktu itu adalah menjelaskan, menafsirkan dan menerjemahkan makna yang terkandung dalam kitab suci, dokumen, jurisprudensi dan teks-teks kuno (Lubis, 2004).

Menurut Palmer (2005: 38), ada enam bentuk definisi hermeneutik yang berbeda yaitu: (1) Teori eksegenesis Bibel; (2) Metode filologi secara umum; (3) Ilmu pemahaman linguistik; (4) Fondasi metodologi Geisteswissenshaften; (5) Fenomenologi eksistensial; dan (6) Sistem interpretasi yang digunakan untuk meraih makna di balik simbol-simbol dan mitos. Keenam definisi ini dapat disebut sebagai pendekatan Bibel, filologis, ilmiah, ilmu-ilmu humaniora, eksistensisal dan kultual.

Dalam perkembangan selanjutnya, hermeneutik tidak saja digunakan sebagai metode untuk menafsirkan teks kitab suci tetapi berkembang sebagai metode penafsiran teks dalam arti yang luas seperti: tanda, simbol, ritual keagamaan, karya seni, sastra, sejarah, psikologi, antropologi dan lainlain. Dengan demikian hermeneutik dapat digunakan untuk menganalisis tentang segala sesuatu yang mengandung makna equivocal dan bukan menjelaskan makna simbol univocal (simbol logika dan matematika) dimana satu simbol hanya memiliki satu makna yang jelas (Lubis, 2004).

Hermeneutik modern merupakan sebuah tradisi interpretatif di Jerman yang menekankan kombinasi investigasi empirik yang detail dan pemahaman subjektif berikutnya mengenai fenomena manusia. Dapatlah dipahami oleh para praktisioner termasuk kritik para ahli sastra, sejarah kesenian, sejarah agama, sosiologi dan teologi termasuk juga antropologi, sebagai alternatif terhadap sastra tekstual, positivisme dan materialisme. Hermeneutik memainkan aturan-turan besar dalam kritik terhadap teori-teori evolusi kultural dan memberikan sumbangan terhadap perkembangan etnografi sebagai investigasi sistem kultural yang detail (Levinson dan Melvin Ember, 1996).

\section{Perempuan dan Laki-laki dalam Kebudayaan Batak Toba}

Kebudayaan Batak berakar pada sistem kekerabatan patrilineal dengan prinsip Dalihan Na Tolu yaitu secara harfiah berarti "Tungku Nan Tiga." Dengan demikian dalam struktur sosial orang Batak Toba terdapat tiga unsur yang didasarkan pada garis keturunan dan sistem perkawinan. Ketiga unsur tersebut adalah dongan tubu atau dongan sabutuha yaitu saudara semarga, hula-hula yaitu sumber istri, dan anak boru yaitu penerima istri. Ketiga unsur ini saling terkait dan membutuhkan. Ketiga unsur ini bersifat relatif dan dapat berubah-ubah (Simanjuntak, 2001: 121). Setiap orang Batak memiliki ketiga posisi tersebut. Ada saatnya menjadi hula hula, ada saatnya menempati posisi dongan tubu dan ada saatnya menjadi boru.

Oleh karena sistem kekerabatan Batak dalam Dalihan Na Tolu bersifat patrilineal, maka laki-laki menjadi pemeran utama dalam berbagai bidang kehidupan perkawinan, hukum, warisan, pemilikan tanah, dan pola tempat tinggal. Laki-laki sejak kecil sudah disosialisasikan bahwa mereka harus memiliki pengetahuan mengenai kebudayaan Batak dan bertanggung jawab terhadap kelangsungan penerusan clan marga ayahnya. Anak perempuan dalam hal ini, dapat dimasukkan ke dalam clan marga ayahnya. Namun demikian, apabila anak perempuan menikah ia kemudian akan dimasukkan ke dalam clan marga suaminya. Dengan demikian dapat dikatakan posisi perempuan dalam kekerabatan Batak Toba adalah ambigu atau tidak jelas, karena meskipun berhubungan dengan kedua clan marga ayah dan suaminya tetapi ia sebenarnya tidak pernah menjadi anggota penuh dari kedua clan marga tersebut.

She is situated between hula-hula and boru, she is associated with both, and an absolute member of neither (Niessen, 1985: 75; Simbolon, 1998: 2; Irianto, 2005: 9).

Tujuan hidup atau misi budaya orang Batak yaitu hagabeon (diberkati karena keturunan), hamoraon (kekayaan), dan hasangapan (kehormatan) dapat dipandang sebagai pedoman mereka dalam bertindak dan berprilaku dalam kehidupannya (Harahap dan Siahaan, 1987: 135) Dalam kenyataannya, misi budaya atau tujuan hidup orang Batak Toba ini dapat dicapai karena adanya andil perempuan di dalamnya. Tujuan hidup orang Batak ini pada masa kini telah mengalami pergeseran makna seiring dengan perkembangan ekonomi, sosial dan politik yaitu menjadi akses kepada modal, tenaga kerja, barang-barang non-material seperti informasi, pengetahuan, pendidikan, 
dan jaringan dengan kaum elit Batak Toba (Simbolon, 1998: 3).

Dalam hubungannya dengan tujuan hidup yang pertama yaitu hagabeon (diberkati karena keturunan), prinsip "banyak anak banyak rezeki" sebenarnya berlaku dalam kehidupan orang Batak. Namun demikian, kecenderungan tersebut telah mulai bergeser bukan lagi banyak anak yang menjadi tujuan melainkan anak yang berkualitas (berpendidikan).

Orang Batak dikenal dengan budaya rantaunya. Pola perantauan mereka disebut juga sebagai perantauan yang "ekspansionis" (Pelly, 1994: 295) dengan motto "mendapatkan anak dan tanah" (halalui anak halalui tano). "Anak dan tanah" bagi mereka adalah simbol "martabat, kekuasaan dan kekayaan" sebagaimana dengan misi budaya mereka.

Sebagaimana juga motto hidup orang Batak Toba "anakkokin do hamoraon di ahu" yang artinya anak adalah harta yang paling berharga. Implikasinya mereka akan berusaha semaksimal mungkin menyekolahkan anaknya walaupun dalam keadaan yang terbatas. Ini menunjukkan bahwa pendidikan anak mendapat tempat dan nilai yang lebih tinggi dari nilai yang lain (Napitupulu, 2011: 273).

Secara kultural memang konseptualisasi orang Batak mengenai anak hanya mengacu kepada anak laki-laki bukan kepada anak perempuan karena istilah anak itu berlaku bagi anak laki-laki sedangkan boru untuk anak perempuan. Dengan dianutnya sistem patrilineal pada orang Batak Toba, hak waris hanya akan diberikan kepada anak laki-laki bukan kepada perempuan.

Menurut Irianto (2000: 268-269), ada tiga alasan mengapa anak perempuan tidak dianggap sebagai ahli waris ayahnya. Pertama, berkaitan dengan konsep Raja Parhata, atau ahli waris yang selalu mengacu kepada anak laki-laki. Kedua, anak perempuan dianggap akan menjadi anggota clan marga suaminya, menjadi clan marga lain, dan melipatgandakan anggota clan marga lain tersebut, dan bersama suaminya sekaligus ikut "menikmati" harta warisan dari mertuanya. Ketiga, dimaksudkan untuk mencegah penguasaan tanah yang terlalu luas oleh pihak clan marga penumpang (terutama suami dari anak perempuan).

Sementara itu, bahkan perempuan janda juga tidak ditempatkan sebagai ahli waris suaminya. Menurut Irianto, (2000:
269) ada dua alasan mengapa perempuan janda tidak ditempatkan sebagai ahli waris suaminya. Pertama, pembuka kampung dan penguasa tanah pertanian (akses produksi) selalu dikaitkan dengan laki-laki. Kedua, sebagai "pasangan", istri dihubungkan dengan konsep persemaian (panamean), "tempat" melahirkan dan membesarkan anak bagi suaminya (akses reproduksi). Dengan demikian janda hanya berhak mengelola dan menikmati harta peninggalan suami semasa hidupnya, sampai anak laki-lakinya cukup besar untuk diserahi harta tersebut. Apabila seorang janda kemudian menikah lagi, maka harta akan kembali kepada keluarga suaminya. Ketentuan ini berlaku sama bagi janda dengan keturunan laki-laki, perempuan ataupun tanpa keturunan (Irianto, 2005: 11).

Menurut Hutabarat (1999: 87) posisi perempuan dalam budaya Batak sebagaimana terwujud dalam sistem Dalihan $\mathrm{Na}$ Tolu tergolong lemah dan tidak setara dengan lakilaki. Ada tiga julukan yang menggambarkan posisi perempuan dalam kebudayaan Batak Toba. Pertama, perempuan disebut sebagai "boru ni rajanami" oleh suaminya yang artinya "putri raja kami". Kendati julukan ini terdengar terhormat, namun dapat diartikan posisi perempuan ditentukan oleh ayahnya, ia adalah bagian dari ayahnya. Kedua, perempuan disebut sebagai "inang soripada" artinya "raja rumah yang dimuliakan," yang lebih menunjukkan peran domestik dari kaum perempuan. Julukan ini sejajar dengan "portalaga" yang artinya, "pelaksana pekerjaan kerumahtanggaan dengan segala macam tetek bengeknya," juga sejajar dengan istilah pardihula dia yang memunyai kepentingan dalam kampung, sedangkan julukan suami adalah pardibalian yang artinya, yang memajukan urusan keluarga di luar cakupan rumah tangga. Ketiga, perempuan dianggap sebagai "pembuka hubungan baru," hanya melalui perkawinan dan melahirkan anak laki-laki, seorang perempuan memiliki makna dan martabat kemanusiaannya dalam masyarakat Batak Toba. Perempuan membuka hubungan kekerabatan baru melalui perkawinan. Tanpa perkawinan ia tidak mempunyai status dan martabat apapun dalam masyarakat Batak Toba.

\section{Ringkasan Karya Sastra "Ende Siboru Tombaga"}

Karya Sastra EST merupakan karya sastra lisan Batak Toba yang berbentuk puisi yang terdiri dari 305 bait dan setiap bait terdiri dari empat larik. Sejarawan Jan Vansina 
menyatakan tradisi lisan sebagai sejarah itu sendiri, mampu menghadirkan fakta-fakta yang kredibel untuk dapat merekonstruksi masyarakat yang selama ini termarginalkan (Purwanto, 2014). Karya sastra ini ditulis oleh Mangarja Pandapotan, kemudian disunting oleh Aisyah Ibrahim dan dicetak pada tahun 1983 melalui Proyek Penerbitan Buku Sastra Indonesia dan Daerah, Departemen Pendidikan dan Kebudayaan Jakarta. Iktisar karya sastra EST ini diambil dan dikutip secara tidak langsung dari pengkajian Sibarani dan Simanjuntak (1999:7-9).

Adapun ringkasan karya sastra EST sebagai berikut:

Tersebutlah seorang raja bernama Raja Ompu Gulas yang tidak memiliki anak lakilaki. Ia hanya memiliki dua anak perempuan yang sulung bernama Siboru Tombaga dan yang bungsu bernama Si Buntulan. Mereka tinggal di kampung Suga-suga dekat tanah Bakkara.

Siboru Tombaga sebagai anak sulung tidak tahan lagi mendengar ejekan orang serta kungkungan adat istiadat karena tidak memiliki saudara laki-laki. Ia meminta ayahnya untuk menikah lagi. Namun, ayahnya menolak dengan alasan sudah tua dan tidak pantas lagi untuk menikah.

Pada suatu hari, Raja Ompu Gulasa jatuh sakit. Penyakitnya semakin lama semakin parah, sehingga Siboru Tombaga menyuruh adiknya memanggil pamannya yang bernama Silitonga. Namun, pamannya tidak menghiraukan panggilan tersebut yang dalam hatinya ia ingin agar abangnya cepat meninggal dan harta kekayaannya jatuh ke tangannya.

Akhirnya Si Buntulan mencari dan memanggil dukun Raja Partungkut Bosi ke kampung Lintong Nihuta untuk mengobati ayah mereka. Apapun akan mereka lakukan agar ayah mereka dapat disembuhkan. Mereka mengadakan acara ritual gendang. Ketika Siboru Tombaga menari di halaman, ayahnya pun menghembuskan nafas yang terakhir di rumah. Si Buntulan pun kemudian membisikkan kematian ayah mereka kepada Si Tombaga. Kesedihan yang mendalam pun dialami mereka. Namun dengan tenang Siboru Tombaga berhenti menari dan naik ke rumah. Dia segera mengunci pintu kamar dan mengemasi emas dan ringgit peninggalan ayah mereka. Ia kemudian memasukkan emas dan ringgit tersebut ke dalam keranjang dan menutupi dengan abu dapur dan menyuruh adiknya untuk menyembunyikannya di kebun. Datanglah kemudian paman mereka untuk melihat jenazah abangnya. Yang pertama-tama ditanyakan adalah harta peninggalan abangnya. Oleh karena tidak dapat menunjukkan harta ayahnya kepada pamannya, Siboru Tombaga akhirnya ditampari, disiksa bahkan dipasung oleh pamannya. Adiknya si Buntulan sempat melarikan diri ke hutan dan masuk ke dalam sebuah gua. Siboru Tombaga menangis sekuat tenaganya sehingga raja-raja di kampung itu mendengar jeritannya itu. Kemudian banyak orang yang datang melihat bagaimana menderitanya Siboru Tombaga dipasung pamannya dan kemudian menjadi kasihan. Mereka akhirnya melepaskan Siboru Tombaga dari pasungan. Dukun yang mengobati Raja Ompu Gulasa pun lari terbirit-birit dan lembu yang diikat untuk acara pengobatan itu dilepaskan.

Akhirnya Siboru Tombaga lari dan mencari adiknya ke hutan dan mereka bertemu di sana. Di sanalah mereka tinggal hingga sampai suatu hari mereka bertemu dengan seorang pemburu yang datang lewat dekat gua mereka.

Lelaki pemburu itu bernama Aman Tornaginjang yang kemudian melamar Siboru Tombaga untuk dijadikan istri. Mereka kemudian pergi ke kampung Aman Tornaginjang yakni Parbotihan. Pemuda yang tampan tersebut mempunyai seorang saudara laki-laki yang bernama Aman Dolok Maria. Si Buntulan akhirnya dijodohkan dan menikah dengan Aman Dolok Maria.

Demikianlah akhir kisah Siboru Tombaga. Baik Siboru Tombaga maupun adiknya Buntulan hidup bahagia bersama suami mereka masing-masing. Akhirnya mereka dapat menikmati harta peninggalan ayah mereka yaitu emas dan ringgit yang sempat mereka sembunyikan.

\section{Penafsiran Karya Sastra "Ende Siboru Tombaga"}

Dalam karya sastra Ende Siboru Tombaga (EST) tergambar bagaimana pentingnya posisi anak laki-laki dalam masyarakat Batak Toba. Harta kekayaan yang melimpah tidak cukup untuk melengkapi kehidupan mereka jika tidak memiliki anak laki-laki. Raja Ompu Gulasa ayah Siboru Tombaga digambarkan sebagai manusia yang tidak lengkap, tidak berharga, tidak sejahtera dan harapannya sudah putus karena tidak memunyai anak laki-laki meskipun dia telah memiliki dua orang anak perempuan dengan 
harta melimpah sebagaimana dinyatakan dalam bait 8 dan 9 berikut ini:

(8) "Marluga ma Simamora, marluga marsadadara, tutu do nian na mora".

"Bersampanlah Simamora,bersampan sendirian, memang benar dia orang kaya, tetapi putranya tiada".

(9) "Na punu do ibana, mate tuan boruna, ndang tumadingkon anak, holan dua do boruna".

"Dia orang yang sudah putus, istrinya meninggal, tanpa melahirkan seorang putra, tetapi hanya dua orang putri" (Sibarani dan Simanjuntak, 1999: 25)

Dikarenakan memikirkan keadaan dan ayah mereka, Siboru Tombaga dan adiknya menganjurkan ayah mereka untuk menikah lagi. Maksudnya tidak lain agar mereka dapat mempunyai saudara laki-laki, sehingga eksistensi mereka diakui dan ayah mereka dihormati orang. Sebagaimana terdapat dalam bait 13 dan 14:

(14) "Ali marbabo na marbaju, ba mangula dolidoli, Amang na sumuan ahu, ua laho Damang mangoli.

"Menyiangi anak gadis, mencangkul anak muda, Ayahandaku, menikahlah Bapak lagi" (Sibarani dan Simanjuntak, 1999: 26).

Pentingnya anak laki-laki dipertegas dalam EST, dimana saat ayah mereka sakit parah, untuk memanggil seorang dukun pun dibutuhkan laki-laki manakala paman mereka tidak mau datang menjenguk ayah mereka. Oleh karena itulah, si Buntulan sampai menyamar dan berpakaian sebagaimana laki-laki untuk memangil seorang dukun sebagaimana bait 34, 35, 44 dan 45:

(34) "Anggi, boru Buntulan, hatop pariban maringkati, manjou datu na sumurung, I ma Raja Partungkot Bosi." "Adinda, Buntulan, cepatlah adikku pergi, memanggil dukun yang mulia, yakni Raja Partungkot Bosi."

(44) "Pardalan ni si Buntulan songon pardalan ni baoa, saraoal marbaju-baju, segar di simanjujungna." "Cara jalan di Buntulan, bagaikan cara berjalan laki-laki, bercelana panjang dan berkemeja, berikat kepala" (Sibarani dan Simanjuntak, 1999: 27).

Kehadiran laki-laki ternyata sangat diperlukan dalam pengobatan ayah Siboru Tombaga. Terbukti dari berkali-kali Siboru Tombaga memanggil dan membujuk pamannya Silitonga untuk menyertai si dukun karena menurut adat pamannyalah seharusnya sebagai ahli waris sebab ayahnya tidak mempunyai anak laki-laki. Namun demikian, pamannya tidak mau datang karena dia ingin agar Raja Ompu Gulasa cepat meninggal sehingga harta kekayaan jatuh ketanggannya, seperti bait 83-85; 91 dan 100 berikut ini:
(84) "Naeng hamu angkupna, donganna manghatai, ai hami na borua, hamu do anak lahi-lahi. "Agar paman menyertai, temannya berunding, karena kami wanita, pamanlah yang laki-laki".

(85)"Na marluga solu, marluga baen dalanku, laho ma ho ito, ai adong dope lolangku."

"Sampan melaju, melaju buat jalanku, pergilah engkau, masih banyak urusanku" (Sibarani dan Simanjuntak, 1999: 27-28; 30-31).

Oleh karena pengobatan ayah Siboru Tombaga tidak dihadiri pihak laki-laki maka pengobatannya dianggap tidak sempurna, sehingga akhirnya ayah mereka meninggal dunia. Dengan demikian harta kekayaan ayah Siboru Tombaga diambil paman mereka kecuali emas dan ringgit yang sebelumnya sempat mereka sembunyikan, sebagaimana bait 170, 176, 183, 190, 235 dan 239 berikut ini:

(190)"Si Boru Buntulan, na pintor dao hapogoan, ditaruhon tu pargadongan, mambahen tu pananoman".

"Si Boru Buntulan, yang pergi dengan cepatcepat, diantarkannya ke ladang ubi, untuk menanamnya."

(239)"Di parmate ni amana, na soada ibotona, sinamot ni amana, dibuat amana Silitonga".

"Ketika ayahnya meninggal, karena tiada saudara laki-lakinya, harta peninggalan ayahnya diambil pamannya Silitonga' (Sibarani dan Simanjuntak, 1999: 36-37).

Kesedihan mendalam bagi Siboru Tombaga dan adiknya bukan hanya akibat meninggalnya ayah mereka namun diperparah karena tidak adanya anak lakilaki sebagai penerus keturunan yang menjadi tempat mengadu mereka. Ini terlihat dari pengulangan (repetisi) bait yang menyatakan kesedihan mereka karena tidak mempunyai saudara laki-laki (bait 8-11; 79-80; 89, 92, $103,131-132 ; 158,161,163-164,167,187$, 239, 241-243 dan 244). Sebagaimana contoh bait berikut ini:

(131) "Dua hami holan borua, dang adong anak ni damang, dohot na so hea niula, nunga pinarsiajaran".

"Kami hanya dua perempuan, ayah tidak mempunyai saudara laki-laki, yang belum pernah kami kerjakan, harus kami pelajari" (Sibarani dan Simanjuntak, 1999: 33).

Siboru Tombaga yang memang sudah membenci pamannya Silitonga karena tidak mau menjenguk ayah mereka yang sedang sakit keras, tidak berkeinginan menyerahkan emas dan ringgit yang sempat disembunyikannya sebagaimana bait berikut ini:

(212)"Laho manean sinamot I, maaringkati ho tu jabu, nialapan ho amang, so olo ho 
mangalusi datu".

"Untuk mengambil harta itu, engkau cepat datang ke rumah kami ini, engkau dipanggil, tidak mau menyertai dukun" (Sibarani dan Simanjuntak, 1999: 41).

Oleh karena Siboru Tombaga tidak berkeinginan untuk memberikan emas dan ringgit tersebut dia disiksa, diikat dan dipasung. Sedangkan adiknya si Buntulan sempat melarikan diri ke hutan sebagaimana bait berikut ini:

(236)"Tu beangan si Tombaga, si Bunatulan pe martabuni, mangangguhi si Tombaga, so adong na mangalusi".

"Si Tombaga di pasung, si Buntulan pun bersembunyi, Si Tombaga menjerit, tiada yang mengacuhkan".

(243)"Adat na hurang ture, di jolma sibirong mata, holan anak do panean di sinnamot ni amana. "Adat yang kurang baik, pada orang bermata hitam, hanya anak laki-laki sebagai ahli waris, terhadap harta ayahnya" (Sibarani dan Simanjuntak, 1999: 34, 42).

Akhirnya Siboru Tombaga dilepaskan oleh pengetua adat dari pasungan karena kasihan kepadanya dan dia pun diusir oleh pamannya. Semua harta mereka kecuali emas dan ringgit yang telah disembunyikan diambil oleh paman mereka sebagaimana bait berikut ini:

(249)"Dung suda sinamot i, dibuat amana Silitonga, dipalaho si Tombaga, manang tunia topotonna". "Setelah harta itu habis, diambil pamannya Silitonga, Si Tombaga diusir, entah ke mana pergi" (Sibarani dan Simanjuntak, 1999: 42).

Setelah melarikan diri ke hutan akibat ulah pamannya, akhirnya Siboru Tombaga bertemu dengan adiknya si Buntulan di hutan sebagaimana bait berikut ini:

(252)"So tampil be tu huta, liang na ma ingananna, dipingkir hinamagona, na so ada tudosanna." "Tidak boleh lagi ke kampung, gualah sekarang tempatnya, memikirkan penderitaannya, yang tiada bandingannya" (Sibarani dan Simanjuntak, 1999: 43).

Suatu ketika mereka bertemu dengan seorang pemburu yang bernama Aman Tornaginjang. Ia terkesan dengan keramahan dan kecantikan Siboru Tombaga dan adiknya. Akhirnya Aman Tornaginjang mencoba melamar Siboru Tombaga. Namun demikian, Siboru Tombaga tidak mau gegabah dia menceritakan terlebih dahulu keadaan dirinya yang sebenarnnya. Usaha Aman Tornaginjang tidak sia-sia akhirnya mereka sepakat untuk menikah sebagaimana bait berikut ini:

(288)"Dung songon I be hata I, marpadan ma nasida, marhata sigabe-gabe, masiummaan ma nasida".

"Setelah saling sepakat, mereka pun mengikat janji, setelah saling memberikan kata petuah, mereka pun bersalaman" (Sibarani dan Simanjuntak, 1999: 44-45).

Kebahagiaan ternyata tidak hanya menyelimuti kehidupan Siboru Tombaga, adiknya di Buntulan juga menikah dengan Aman Dolok Maria adiknya Aman Tornaginjang. Akhirnya Siboru Tombaga dan adiknya hidup bahagia bersama suami masing-masing. Harta yang mereka perjuangkan akhirnya dapat bermanfaat dan memberikan andil dalam kehidupan mereka. Sejak kejadian itu para raja pun mulai memertimbangkan perempuan dalam pembagian warisan akibat perjuangan yang gigih dari Siboru Tombaga dan adiknya sebagaimana bait berikut ini:

(302)"Olat ni na masa I, marpingkir ma angka raja, di langka ni siteanon, dohot ma boru nampunasa".

"Sejak kejadian itu, para raja pun berpikir, dalam hal warisan, ikutlah wanita sebagai ahli waris".

(303)"Marguna ma hae, partianonan ni si Tombaga, gabemambahen turgas, tu angka raja-raja".

"Bermanfaatlah, penderitaan di Tombaga, untuk memberikan pertimbangan, kepada raja-raja" (Sibarani dan Simanjuntak, 1999: 46).

\section{Refleksi Tafsir Karya Sastra Ende Siboru Tombaga}

Pentingnya laki-laki dalam setiap aspek kultural kehidupan orang Batak tampak seperti dalam perkawinan, hukum, warisan, pemilikan tanah dan pola tempat tinggal. Dapat dikatakan hampir semua persoalan adat yang memegang peranan penting dan melaksanakannya adalah laki-laki. Dalam EST digambarkan pengobatan ayah Siboru Tombaga tanpa laki-laki dianggap pengobatan yang tidak sempurna sehingga berakibat meninggalnya ayah mereka.

Kungkungan adat yang demikian kuat digambarkan dalam EST sebenarnya menyengsarakan dan membuat kesedihan yang mendalam baik bagi perempuan maupun bagi laki-laki dikarenakan tidak memiliki anak laki-laki. Eksistensi keluarga yang tidak memiliki anak laki-laki bahkan dianggap tidak lengkap, tidak sejahtera dan lebih rendah dari yang lain meskipun mereka dari keluarga yang kaya raya.

Dahulu, anak-anak perempuan yang tidak memiliki saudara laki-laki akan 
menunjukkan sikap dan perilaku yang berbeda. Dengan kata lain anak-anak perempuan tersebut menunjukkan simbolsimbol yang berbeda dengan anak lainnya yang mempunyai saudara laki-laki. Menurut Sibarani dan Simanjuntak (1999: 50), anak perempuan yang tidak memiliki saudara lakilaki, antara lain, akan terbatas berpakaian, bergerak dan bergaul (sulit menemukan jodoh), merasa terasing dari lingkungannya seperti pepatah "songan tandiang na hapuloan" artinya, "orang yang terasing/ terisolir." Selain itu, pada saat menari tor-tor perempuan yang tidak memunyai saudara laki-laki melilitkan ulos di antara pinggang dan ketiaknya sedangkan perempuan yang memunyai saudara laki-laki melilitkan ulos di pinggangnya. Ritual kematian orangtua pun dianggap lebih rendah tingkatannya.

Dapat disimpulkan bahwa orang yang tidak memunyai anak laki-laki dahulu akan mengalami hal-hal sebagai berikut: (1) "Dang boi pajongjong adat di harajaon" yang artinya "tidak dapat mengadakan pesta besar' seperti "ulaon turun" yaitu "pesta tambak"; (2) Tidak ada penerus marga (putus marga); (3) Saat meninggal, tidak dilakukan ritual saurmatua; (4) "Boru siparsondak ibana" yang artinya "putri yang akan menguruskan orang tuanya semasa hidup sampai meninggal dunia" yang seharusnya adalah laki-laki; (5) Tidak memiliki "hula-hula" pemberi istri (perempuan) yang dapat berfungsi memberikan berkat secara kultural; (6) "Songon tandinag na hapuloan" yang artinya "merasa terasing"; (7) "Mangkel di sihapataran, tangis di sihabunian" yang artinya "tertawa di tempat ramai, tetapi menangis di tempat tersembunyi" (Sibarani dan Simanjuntak, 1999: 51).

Selain itu, dalam cerita rakyat Si Galegale (SGG) yang ditulis kembali oleh Rayani Sri Widodo menggambarkan bahwa perempuan Batak Toba, apabila sudah menikah dan kemudian meninggal tanpa memiliki anak maka dipercaya rohnya tidak akan diterima di alam baka (Nurelide, 2007: 125). Anak yang dimaksud dalam cerita ini tentunya berorientasi pada anak laki-laki. Cerita Si Gale-gale ini juga merupakan sebuah tradisi lisan yang unik diwujudkan dalam seni patung yang dikenal dengan nama Si Gale-gale. Si Gale-gale muncul dalam acara penguburan dimana ia berfungsi sebagai anak laki-laki. Orang yang mati tanpa meninggalkan anak cucu dianggap mati tidak sempurna. Biasanya pada upacara kematian bagi orang yang mati tanpa keturunan, diadakan tortor (tari) Si Gale-gale (Nurelide, 2007: 12). Makna dari cerita Si Gale-gale ini menggambarkan bagaimana lemahnya posisi perempuan apabilah tidak menikah, menikah tapi tidak memiliki anak laki-laki dan menikah kemudian meninggal tanpa memiliki anak laki-laki. Jadi dengan kata lain tanpa perkawinan dan tanpa memiliki anak laki-laki perempuan tidak mempunyai status dan martabat apapun dalam masyarakat Batak Toba.

Begitu pentingnya laki-laki dalam kebudayaan Batak membuat posisi perempuan demikian lemah. Bahkan hanya dengan melahirkan anak laki-laki lah perempuan dianggap memiliki martabat kemanusiaannya. Dalam kenyataannya tidak mengherankan melihat seorang istri Batak melahirkan anak perempuan terusmenerus sampai akhirnya mendapatkan anak laki-laki. Sering sekali perempuanlah yang dijadikan pihak yang bersalah karena tidak mendapatkan keturunan laki-laki. Anggapan demikian tentu saja sangat merugikan kualitas hidup perempuan.

Dalam hal ini,tampak adanya paradoks cara orang Batak menempatkan perempuan dalam aspek kulturalnya. Dalam kenyataannya, perempuan Batak Toba dari dulu dikenal sebagai "pekerja" keras, tangguh dan perkasa. Di daerah asalnya mereka dikenal sebagai petani dan peladang yang giat bekerja mengolah sawah maupun ladang milik keluarga pihak suaminya. Tidak mengherankan bila melihat mereka bekerja sambil menggendong anak yang masih balita di punggungnya.

Sebagai migran informal perempuan Batak Toba juga dikenal sebagai parlangsam yaitu sebagai orang yang mengumpulkan pakaian-pakaian dan barang-barang bekas untuk dijual kembali. Sementara di perantauan, kiprah mereka di dunia dagang dikenal dengan sebutan inang-inang. Kegiatan ekonomi yang dilakukan inang-inang di Medan merupakan kegiatan yang banyak menyita waktu dan tenaga dengan penghasilan yang memungkinkan mereka untuk menyekolahkan anak-anaknya dengan baik. Pendidikan bagi orang Batak Toba memanglah satusatunya jalan untuk mencapai "kemuliaan hidup". Perempuan pedagang Batak Toba (inang-inang) dengan aktifitas dagangnya sepenuhnya telah mengemban tugas untuk mewujudkan misi budaya tersebut. Terlepas dari semua pekerjaan yang dilakukan perempuan, perempuan Batak Toba juga mau tidak mau berfungsi sebagai mediator terutama dalam ritual-ritual adat Batak Toba. 
Oleh karena yang memersiapkan segala sesuatunya dalam berbagai ritual umumnya adalah perempuan. Dengan kata lain, tanpa kehadiran perempuan berbagai ritual tidak akan berjalan sebagaimana mestinya (Bemmelen, 1992: 135-165).

Begitu paradoksnya peran perempuan dalam sistem kekerabatan orang Batak Toba. Namun dalam kenyataannya, pihak keluarga yang tidak memiliki anak perempuan tidak akan pernah menjadi pihak "hula-hula" (pemberi istri). Dalam sistem kekerabatan Batak Toba pihak hula-hula inilah yang dianggap memiliki kedudukan tertinggi dalam struktur Dalihan Na Tolu dan sangat dihormati karena dapat memberikan pemberkatan dalam setiap ritual orang Batak.

Hula-hula ini dapat dianggap penjelmaan dari Mula Jadi Nabolon (penggantinya Tuhan Yang Maha Kuasa). Dikatakan bahwa hulahula adalah Tuhan yang terlihat (debata na tarida). Atau dalam peristilahan lain hula-hula adalah wakil ni De bata (khalifatullah) karena merupakan pihak yang telah memberikan istri. Hula-hula adalah sumber kekuatan adikodrati, daya hidup yang memberi semangat kepada boru-nya (Vergouwen, 1986: 55-56). Namun demikian tetap saja kalau dalam sebuah keluarga ada anak perempuan tapi tidak ada anak laki-laki keluarga tersebut juga tidak bisa menjadi pihak hula-hula.

Sebagaimana yang dikemukakan oleh Djoeffan (2001), dalam kondisi penurunan kesejahteraan keluarga dan rumah tangga umumnya perempuan terdorong untuk berperan serta membantu kesejahteraan keluarga. Berbagai penelitian bahkan mengungkap usaha yang dilakukan perempuan bukan saja membantu kehidupan keluarga melainkan menjadi tumpuan dan nafkah utama dalam kehidupan keluarganya sebagaimana kasus inang-inang di Medan. Rahminawati (2001) menyatakan bahwa dalam realita kehidupan, hampir semua tugas gender dapat dilakukan oleh kedua kaum, baik laki-laki dan perempuan.

Menurut Ihromi (1975: 357) prinsip keturunan yang ada dalam sebuah kebudayaan akan membawa pengaruh terhadap peran dan status perempuan dan laki-laki pada masyarakat tersebut. Lebih lanjut Ihromi (1994:525) menyatakan bahwa dominasi laki-laki pada budaya Batak tampil pada norma-norma yang dijalani yang memberi perempuan status yang lebih rendah. Status dan kedudukan yang rendah inilah yang menempatkan perempuan Batak Toba tidak diperhitungkan dalam hal ahli waris.

Dari dulu hingga sekarang prinsip keturunan patrilineal yaitu konsep bahwa anak laki-laki sebagai penerus marga tidak mengalami perubahan. Sejak masuknya misi kristenisasi di daerah Tapanuli Utara, akses anak perempuan dalam pendidikan sudah mulai terbuka. Solusi terhadap tidak adanya anak laki-laki dalam perkembangannya sekarang adalah dibolehkan dan dianjurkannya mengadopsi anak laki-laki. Secara adat, adopsi anak laki-laki ini dinyatakan sah adanya. Namun demikian, penerimaan pihak laki-laki yang menjadi ahli waris cenderung akan melakukan penolakan. Hal inilah yang sering menimbulkan konflik dalam perebutan harta warisan. Dalam agama Kristen, poligami sebenarnya dilarang, namun demi mendapatkan anak laki-laki seorang laki-laki Batak secara adat didukung untuk melakukannya dengan dalih agar penerusan marga tetap dapat berlangsung.

Dalam karya EST terlihat pengarang berulang-ulang menyatakan ketidakadilan, kejahatan, ketidakbenaran dan diskriminasi terhadap perempuan Batak yang dalam hal ini tidak memiliki saudara laki-laki terutama sekali dalam hal warisan. Karya sastra EST dapat dianggap sebagai suatu strategi budaya atau solusi bagi persoalan masyarakat Batak yang tidak memiliki anak laki-laki.

Dewasa ini semakin banyak perempuan yang menuntut hak warisnya lewat pengadilan atau hukum positif pemerintah. Sebagaimana yang dikemukan oleh Irianto (2005:300), keadaan ini menyebabkan kelompok perempuan tertentu menciptakan budaya hukum dan sub budaya hukumnya sendiri, yaitu tercermin melalui cara perempuan Batak Toba memilih institusi peradilan dalam proses penyelesaian sengketa waris.

\section{Simpulan dan Saran}

Paradoks perempuan Batak Toba ditandai dengan situasi bahwa secara kultural orang Batak Toba dengan sistem patrilinea/nya menempatkan laki-laki sebagai pemeran utama dalam berbagai bidang kehidupan termasuk dalam hal nafkah yang seharusnya akan diperolehnya dari suami yang akan menjamin kehidupannya. Dalam realitasnya perempuan Batak Toba dikenal dari dulu sampai sekarang berperan penting dalam kehidupan masyarakatnya termasuk bekerja keras dalam menafkahi keluarga dan rumah tangganya. 
Dengan demikian, diperoleh beberapa kesimpulan menyangkut nilai-nilai budaya yang penting tergambar dalam karya sastra EST. Pertama, karya sastra EST mencerminkan masyarakat budaya Batak Toba. Kedua, EST menggambarkan bagaimana hak dan kedudukan perempuan Batak Toba yang tidak mempunyai saudara laki-laki. Ketiga, sebagaimana yang tercermin dalam EST, masyarakat Batak Toba masih beranggapan bahwa anak laki-laki lebih penting dibandingkan anak perempuan. Adapun alasannya karena laki-laki merupakan penerus marga (sistem kekerabatan patrilineal) dan pentingnya peran dan kedudukan laki-laki dalam adat istiadat Batak Toba. Keempat, perempuan biasanya tidak diperhitungkan dalam pembagian warisan terutama pada zaman dulu. Kelima, jika perempuan tidak memiliki saudara lakilaki sebagaimana tergambar dalam EST dia tidak boleh mendapatkan harta waris ayahnya. Harta warisan akan jatuh ke tangan adik ayahnya (paman) atau putra adik ayah. Keenam, dalam karya sastra EST terlihat bagaimana dinyatakan secara berulang-ulang ketidakadilan, kejahatan, ketidakbenaran dan diskriminasi terhadap perempuan Batak yang tidak memiliki saudara laki-laki terutama sekali dalam hal warisan.

Karya sastra EST dapat dianggap sebagai suatu strategi budaya atau solusi bagi persoalan masyarakat Batak yang tidak memiliki anak laki-laki dan memberikan dasar yang cukup sah dalam budaya bahwa perempuan sebaiknya juga diperhitungkan dalam hal warisan. Dengan kata lain, karya sastra EST dapat dianggap sebagai counter culture terhadap adat istiadat yang cenderung dianggap mendiskriminasi perempuan. Dengan demikian sudah sewajarnyalah perempuan dalam masyarakat Batak Toba diperhitungkaan dalam pembagian harta warisan mengingat dalam kenyataannya pentingnya keberadaan perempuan dalam setiap aspek kultural kehidupan masyarakat Batak Toba.

\section{Daftar Pustaka}

Bemmellen, van Sita. (2005). "The Contruction of Toba Batak Gender: Recurrent Themes,"Jurnal Antropologi Sumatera, Vol. 2, No. 3, pp. 186-225.

Djoeffan, Sri Hidayati. (2001). "Gerakan Feminisme di Indonesia: Tantangan dan Strategi Mendatang," Mimbar Jurnal Sosial dan Pembangunan, Volume 17, No. 3, pp. 284-300.
Harahap, B. H dan Hotman M. Siahaan. (1987). "Orientasi Nilai-nilai Budaya Batak Suatu Pendekatan terhadap Perilaku Batak Toba Angkola-Mandailing," Jakarta, Sanggar Willem Iskandar.

Hutabarat, Rainy. (1999). "Perempuan dalam Budaya Batak: Bori ni Raja, Inang Soripada dan Pembuka Hubungan Baru, "Gema Duta Wacana, Edisi 55, pp. 77-88.

Ihromi, T. O. (1975). "Social Cultural Background of Concepts of Role of Women," Ecuremical Review, Vol. 27, No. 4, pp. 357-365.

Ihromi, T. O. (1994). "Inheritance and Equal Rights for Toba Batak Daughters," Law and Society Review, Vol. 28, No. 3, pp. 525-537.

Irianto, Sulistyowati. (2000). Reproduksi dan Resistensi terhadap Patriarkhi: Pewarisan Perempuan dalama Kebudayaan Batak Toba yang Tengah Berubah, dalam: E. Kristi Poerwandari dan Rahayu Surtiati Hidayat, (Ed.) "Perempuan Indonesia dalam Masyarakat yang Tengah Berubah,"Jakarta, Program Studi Kajian Wanita Program Pascasarjana Universitas Indonesia, pp. 268-269.

Irianto, Sulistyowati. (2005). 'Perempuan Diantara Berbagai Pilihan Hukum (Studi Mengenai Stategi Perempuan Batak Toba untuk Mendapatkan Akses Kepada Harta Waris Melalui Proses Penyelesaian Sengketa)', Jakarta, Yayasan Obor Indonesia.

Levinson, David dan Melvin Ember. (1996). 'Encyclopedia of Cultural Anthropology', Vol. 2, New York, Henry Holt and Company.

Lubis, Akhyar Yusuf. (2004). Filsafat IImu dan Metodologi Posmodernisme, Bogor, AkaDemiA.

Napitupulu, V. M. (2011). Pendidikan sebagai Faktor Dinamisasi dan Integrasi Sosial dalam Masyarakat Tapanuli Utara, dalam: Bungaran Antonius Simanjuntak (Ed.) Pemikiran tentang Batak Setelah 150 Tahun Agama Kristen di Sumatera Utara, Jakarta, Yayasan Pustaka Obor Indonesia, pp. 271-278.

Niessen, Sandy A. (1985). "Motifs of Life in Toba Batak Text and Textilles," Dordrecht/Holland Cinnaminson /USA, Foris Publication.

Nurelide. (2007). "Meretas Budaya Masyarakat Batak Toba dalam Cerita Sigale-gale." Semarang, Magister IImu Sastra Universitas Diponegoro. Tesis.

Palmer, Richard E. (2005). Hermeneutika Teori Baru Mengenai Interpretasi, Yogyakarta, Pustaka Pelajar. 
Pelly, Usman. (1994). Urbanisasi dan Adaptasi: Peran Misi Budaya Minang dan Mandailing, Jakarta, LP3ES.

Purwanto, Bambang. (2014). "Belajar dari Afrika: Tradisi Lisan sebagai Sejarah dan Upaya Membangun Histiografi bagi Mereka yang Terabaikan," dalam: Jan Vansina (Ed.) Tradisi Lisan sebagai Sejarah, Yogyakarta, Ombak.

Rahminawati, Nan. (2001). "Isu Kesetaraan Laki-Laki dan Perempuan (Bias Gender)," Mimbar Jurnal Sosial dan Pembangunan, Volume 17, No. 3, pp. 273-283.

Sibarani, Robert dan Peninna Simanjuntak. (1999). Hak dan Kedudukan Wanita Batak Toba yang tidak Mempunyai Saudara Laki- laki dalam Pembagian Harta Warisan: Sebuah Kajian Sosiologi Sastra, Laporan Penelitian, Universitas Sumatera Utara

Simanjuntak, B. A. (2001). Konflik Status dan Kekuasaan Orang Batak Toba, Yogyakarta, Jendela.

Simbolon, Indira, Juditka. (1998). Peasant Women and Access to Land Customary Law, State Law and Gender-Based Ideology The Case of the Toba-Batak (North Sumatera). Ponsen \& Looijen b. v. Wageningen Dissertation.

Vergouwen, J. C. (1986). Masyarakat dan Hukum Adat Batak Toba, Yogyakarta, LKIS. 